ĐANI MOHOVIĆ, Ph.D.

E-mail: dmohovic@pfri.hr ROBERT MOHOVIĆ, Ph.D.

E-mail: mohovic@pfri.hr

IGOR RUDAN, Ph.D.

E-mail: rudan@pfri.hr

University of Rijeka, Faculty of Maritime Studies

Studentska 2, 51000 Rijeka, Croatia
Transport in Emergency

Preliminary Communication

Accepted: Nov. 27, 2012

Approved: Sep. 24, 2013

http://dx.doi.org/10.7307/ptt.v25i5.1194

\title{
SIMULATION OF SHIP MOVEMENT AFTER STEERING SYSTEM FAILURE TO DETERMINE THE WORST CASE SCENARIO OF GROUNDING
}

\begin{abstract}
Ship grounding is one of the primary maritime navigation casualties and a result of an error made by the navigating officer, of a technical failure on vital ship equipment or of force majeure. In order to decrease the risk of grounding in such cases, this paper explores the ship movement during navigation when an extraordinary event occurs, such as steering system failure that affects the vessel's direction directly and speed indirectly. One way to determine the ship movement in such circumstances is by simulating the ship movement on the navigational simulator according to the predefined scenarios, as explained in this paper. A total of 60 scenarios were researched, in the process of which ship type, ship size, ship speed and rudder deflection angle were varied. During the simulation, all relevant data concerning current movement of the ship and a graphical display of the performed simulation were recorded every 30 seconds. On the basis of the simulation results it is possible to determine the worst case scenario which can be used to define the consequence of grounding, one of the parameters necessary for the assessment of the risk of grounding.
\end{abstract}

\section{KEY WORDS}

risk of grounding, failure of the steering system, ship movement simulation, selection of the worst case scenario

\section{INTRODUCTION}

The term "risk" is used in everyday life and can be applied in many procedures and activities. According to the International Maritime Organization (IMO) [1], risk is the degree of probability that an undesired event will occur along with the extent of consequences of the event within a certain period of time, i.e. the combination of the frequency of the casualty and the severity of its consequences. Given their magnitude, maritime risks belong to the group of great risks, right next to risks of natural catastrophes, war risks and risks in industries of processing and manufacturing dangerous materials.

Maritime risks represent risks of occurrence of dangers specific to maritime traffic. This definition defines risks broadly and includes all risks that can take place during ship voyage, ship's stay in port, loading/ unloading operations, repair, as well as financial risks, etc. Considering the aim of this paper, the definition should be narrowed to maritime navigational risks.

Maritime navigational risks are risks of occurrence of those dangers that are characteristic to maritime traffic and take place while the vessel is underway. According to the International Regulations for Preventing Collisions at Sea 1972 (COLREG), the term underway signifies that the vessel is not anchored, moored or grounded.

Various methods are used for risk assessment, but they do not answer the questions whether the assessed risk is too great, should certain measures of risk reduction be taken, what is the effect of the measures implemented, etc. This very fact imposed the need for determining the so-called acceptable risk that demands implementing the risk management principle. In this process, the adequate risk assessment is not qualitative but quantitative risk assessment that estimates the risk of a certain activity assigning it a certain numerical value. The acceptable risk represents the level of risk society is aware of and willing to accept.

Ship grounding is one of the most common maritime navigation casualties that take place at sea, whereat human casualties are rare, but pollution with negative effects to the environment is not. The acceptable risk principle does not demand complete elimina- 
tion of the risk of grounding, but solicits that the risk of grounding be acceptable regardless of the type of vessel, type of cargo or the area in which the vessel navigates.

To enable determining the acceptable value of the risk of grounding, it is necessary to define possible scenarios of ship grounding and to examine ship movement in various scenarios. The aim of this paper is to define and analyze ship movement scenarios that lead to grounding and are result of the steering system failure. Therefore, the paper analyzes possible ship grounding causes, types of grounding, as well as ship systems that affect the facility of ship direction control directly and ship speed indirectly.

Based on the conducted analyses, the scenarios for different ship types and sizes, examined on the navigational simulator Transas NTPro 4000 installed at the Faculty of Maritime Studies in Rijeka, are predefined. The navigational simulator used possesses Certificate "Class A - Standard for certification of maritime simulators No. 2.14" issued by the Det Norske Veritas - DNV. The results of the simulations enabled determining the ship movement trajectory upon the occurrence of an extraordinary event during navigation. For reasons of using the obtained results for assessing the risk of grounding, ship trajectories were analyzed with the assumption that the vessel navigates within a limited fairway. The obtained results enable selecting the worst case scenario, for which the severity of the consequence can be determined in the next phase and risk magnitude can finally be estimated.

\section{GROUNDING CAUSES AND TYPES}

Ship navigation is determined by the ship's position on a certain part of the fairway from the place of departure to the place of arrival. During the voyage, in a given period of time the vessel changes direction and speed. Navigation itself can be viewed from two possible aspects:

- during the voyage all onboard systems are functioning properly, and the person managing the ship practices "good seamanship",

- during the voyage an extraordinary event occurs, which affects the possibility of maintaining the desired direction and/or speed.

The former represents ship navigation in the fairway that meets safe navigation conditions for the considered vessel. In such cases, ship navigation can be considered safe, with the assumption that all systems onboard function properly and that the person managing the ship practices "good seamanship".

The latter presupposes an extraordinary event occurrence that will disrupt maintaining the desired direction and/or speed. In addition, it is assumed that the extraordinary events (failures) occurred in the steer- ing system and/or the propulsion system. It is presupposed that the person managing the ship and other crew members practice "good seamanship" in the situation of this type of an extraordinary event as well.

Generally, grounding is a type of maritime casualty that involves contact of the vessel's hull with sea bed that results in damaging the underwater part of the vessel's hull, especially the bottom of the vessel, and that can lead to flooding of the vessel's compartments. Grounding causes great load to the structure of the vessel and is one of the most significant maritime casualties with regard to the consequences. In minor casualties, it can result in lesser hull damage, while in severe casualties grounding can cause oil spills, loss of human lives or loss of the entire vessel.

Groundings are most commonly divided into two basic groups:

- groundings in which the propulsion system was generating propulsion at the moment of grounding (Powered Grounding), and

- groundings in which the propulsion system was not generating propulsion at the moment of groundings, and grounding was not a result of the remaining kinetic energy of the vessel but of the effect of the external forces to the vessel (wind, waves, sea current) (Drift Grounding).

Apart from these basic groups most commonly mentioned in literature, there are other types of grounding, such as grounding of an anchored ship, grounding of a ship onboard which an extraordinary event took place, etc. In the continuation of this paper, ship movement during voyage after the occurrence of an extraordinary event that suggests a failure in the steering system is examined.

Grounding in which the propulsion system was generating propulsion at the moment of grounding occurs when the vessel is moving forward or backward under propulsion, and the most common cause of grounding is navigational error [2]. In [3] the authors state that the primary reasons for this type of grounding are fundamental errors in the process of voyage planning and/or executing. Errors in the navigational charts, or improper updating of navigational charts, are the second most common reason of this type of grounding.

Groundings in which the propulsion system was not generating propulsion at the moment of grounding, i.e. grounding was caused by wind, waves and sea currents, mostly take place after a mechanical failure [2], such as engine failure or the failure of the steering system. Unfavourable weather conditions along with impossibility or inefficiency of anchorage or unavailability of towage are primary causes of this type of grounding, Figure 1.

Depending on the type of the sea bottom that the vessel grounded on, groundings are divided into [4]:

- "soft" groundings, and

- "hard" groundings. 


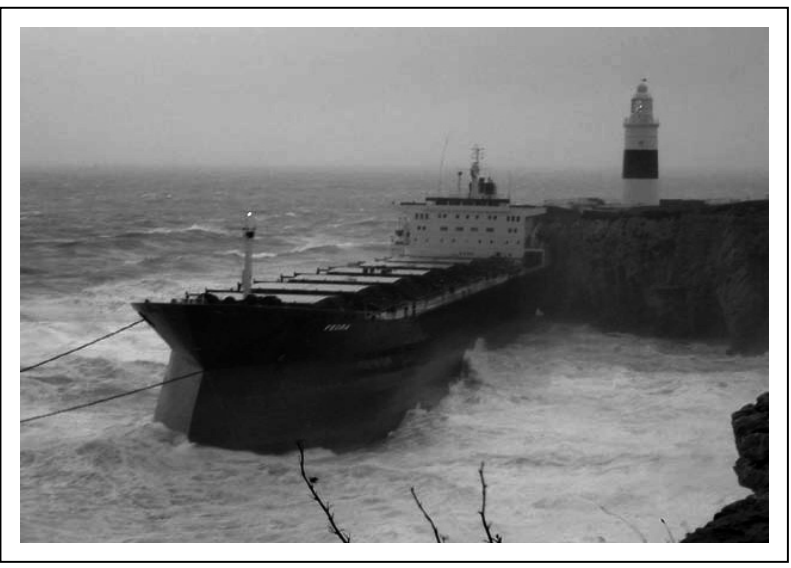

Figure 1 - Liberian bulk carrier "Fedra" grounded in the southernmost part of Gibraltar

Source: www.maritime.com, 09/09/2012

"Soft" grounding is grounding of a vessel on a sandy or silty sea bottom, and "hard" grounding is when the vessel grounds on a rocky sea bottom.

\section{ANALYSIS OF THE EFFECT OF PROPER OPERATION OF SHIP SYSTEMS TO SHIP MOVEMENT}

In view of the aim of this paper, the inability to control the vessel's direction or speed is considered an extraordinary event. In order to properly examine ship movement after the occurrence of an extraordinary event on the navigational simulator, it is necessary to define the possible scenarios. It is known that the ship speed is controlled by using the propulsion engine, while the direction is controlled by the appropriate rudder deflection. This is true for most vessels, but there are vessels that facilitate various means of direction control (for example, ships with azimuth thrusters, water jet propulsion, etc). Possible cause-and-effect sequence of the analyzed extraordinary events is shown in Figure 2.

Therefore, hereafter the paper analyzes ship systems that directly or indirectly affect the capacity to control ship speed and direction, namely:

- propulsion engine system,

- steering system,

- power supply system.

In case of a failure in the propulsion engine system, time necessary for repairing the failure and restoring proper system operation depends on the cause of the problem in the propulsion system. The crew is able to eliminate some failures within shorter or longer periods of time, while other failures require towing the vessel to the place where the engine repair work is to be performed.

If the vessel is near enough to the grounding area at the moment of propulsion system failure, it can be assumed that the vessel's crew will probably not be able to eliminate the failure from the moment of the extraordinary event occurrence till grounding. Furthermore, it is not certain that the steering system failure will take place along with propulsion engine failure. This assumption allows for the scenario in which a propulsion engine failure takes place, the vessel continues to move due to inertia at the moment of the failure occurrence, and the steering gear is used to keep the vessel within the planned trajectory. Among other factors, efficiency of the steering gear also depends on the velocity of water inflow to the rudder. Decreased flow of water roundabout the rudder causes reduction of rudder efficiency, and at a certain point, it is no longer possible to control the direction of the vessel's movement by the appropriate rudder deflection. The vessel then continues to move without any control by the vessel's crew, and further movement depends on the remaining inertia and the resulting force of the external conditions.

In case of propulsion system failure, it is possible to use the anchoring system for the purposes of grounding prevention. However, to do so, certain conditions must be met, such as appropriate water depth, sufficiently low ship speed, type of sea bottom appropriate for anchorage, etc., that significantly limit this option; thus, it is not taken into consideration in this paper.

Tugboats can also be used to control ship movement in case of propulsion system failure. Availability of tugboats in case of an extraordinary even depends on their position in relation to the location of the extraordinary event and their disposability. As the assumed extraordinary events can occur at any part of the fairway, and not just in port areas, the possibility of using tugboats in case of an emergency event is not considered.

In cases of steering gear failure, possible causes of incapacity of rudder control are failures in the system of command transmission between the navigation bridge and the rudder, failures on the steering system power supply, and failures on the steering device. The possibility of repairing the failure or using the auxiliary steering system depends on the problem disabling rudder control.

Regardless of the cause of the failure, the result of the steering system failure is a certain angle of rudder deflection that is impossible to rectify. Possible angles of rudder deflection vary from minimum angle (rudder in the centre, or a small rudder deflection port or starboard) to maximum rudder deflection angle.

Considering the above, in defining the ship movement scenario to be examined on the navigational simulator, different rudder deflection values after the occurrence of the extraordinary event will be assumed. It will also be assumed that the crew was not able to enable one of the steering means within a short period after the failure took place. 
Based on the factors mentioned above, in this research the scenarios will be assumed in which a steering gear failure and a certain rudder deflection take place and cannot be repaired, but the engine can be utilized, and it is assumed that the person conducting the ship will stop the engine. In such cases, it can be assumed that the engine may run astern, which depends on the engine characteristics and the ability of the person conducting the vessel to make crucial decisions [5]. When the vessel is at a considerable distance from the coast or when she navigates at low speed, such a scenario is possible, but when the vessel is near the coast or navigates at high speed, this scenario is very doubtful. Thus, in defining the scenarios, the authors of this paper assume that while the vessel speed is decreasing, the engine will not run astern.

Failure of the power supply system does not directly affect the vessel speed and direction, but disables the systems on which the possibility of vessel control depends (propulsion engine system and steering system). The power supply system usually consists of two or more generators, and an emergency generator. When the vessel navigates in dangerous areas, the crew must ensure power supply with the minimum of double redundancy, i.e. two or more generators in the network.

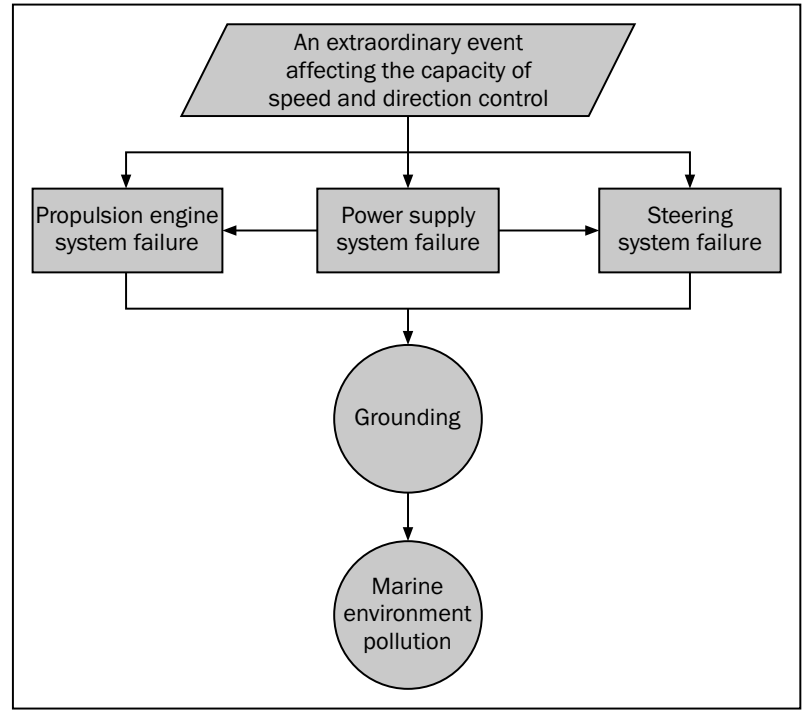

Figure 2 - Cause-and-effect sequence of the described extraordinary events

When the main generators cannot be utilized, the power supply emergency generator is started that can supply the steering gear, but not the main engine. Whether there will be sufficient time to restore all systems to avoid grounding primarily depends on the distance between the vessel and the coast, and the speed of the vessel at the moment of the occurrence of the extraordinary event.

Consequences that cause power supply system failure assume the same scenarios as already described in this chapter.
It should be noted that there are other extraordinary events and other consequences that can occur onboard a vessel, but these are omitted in defining the scenarios due to the aim of this paper.

\section{RESEARCH OF SHIP MOVEMENT AT THE OCCURRENCE OF AN EXTRAORDINARY EVENT}

In determining the probability of grounding, which is one of the elements necessary for risk assessment, the trajectory the vessel will follow in various scenarios of an extraordinary event should be defined. The ship trajectory can be obtained in the following manners:

- in situ - determining various trajectories using a real vessel and a specific navigation area;

- determining ship movement trajectories using the existing track models;

- determining ship movement trajectories using a navigational simulator.

In situ trajectory determination for different ship types and sizes under various conditions requires considerable amount of time and costs. Undoubtedly, this method provides the most accurate data and may be considered feasible. However, for reasons of necessary time and costs, it is not often applied.

Ship track models have been studied by a number of authors $[6,7,8,9,10]$. Such studies are limited to one or several different ship types and sizes for which model calibration was performed using a certain vessel, the movement of which was to be modelled. The disadvantage of such models lies in the fact that certain simplifications and neglect have emerged in the process in order for the model not to be too complicated, thus not all ship types and sizes can be applied.

Navigational simulators have become an inevitable part of education of students and mariners on ships alike. In addition to this primary role, navigational simulators are increasingly frequently utilized for analyzing ship movement trajectory, and the results obtained in this manner are used for fairway projecting. The advantages of using the simulator in comparison with the models described above are that the trajectories of man-navigated vessels are researched, so not only model behaviour is examined, but human behaviour as well.

As is the case with models of various authors, the shortcoming of the simulation models is that they simulate movement of only certain ship types and sizes for which there are data bases available in the simulator. For the purposes of this research, ship types that would cause severe consequences in case of grounding were chosen in the navigational simulator. According to the selected criterion, those are tankers, because of the type of cargo, and large bulk carriers, because they have fuel tanks of large capacity. The se- 
Table 1 - Overview of selected ship types and sizes

\begin{tabular}{|c|c|c|c|c|c|c|}
\hline Vessel type & Displacement (t) & $\begin{array}{l}\text { Loa } \\
\text { (m) }\end{array}$ & $\begin{array}{c}\text { B } \\
(\mathrm{m})\end{array}$ & $\begin{array}{c}\mathrm{T} \\
(\mathrm{m})\end{array}$ & $\begin{array}{l}\text { DSA } \\
\text { (kn) }\end{array}$ & $\begin{array}{c}\text { FA } \\
\text { (kn) }\end{array}$ \\
\hline Chemical tanker & 44,288 & 182.6 & 27.3 & 10.9 & 5.4 & 14.5 \\
\hline Oil tanker & 77,100 & 242.8 & 32.2 & 12.5 & 5.5 & 15.0 \\
\hline VLCC 4 & 137,092 & 249.9 & 44.0 & 15.4 & 5.8 & 14.7 \\
\hline Bulk carrier & 202,000 & 290.0 & 46.0 & 18.1 & 6.0 & 14.6 \\
\hline VLCC 2 & 321,260 & 332.0 & 58.0 & 20.8 & 5.5 & 15.7 \\
\hline
\end{tabular}

Source: Navigational simulator TRANSAS NTPro 4000

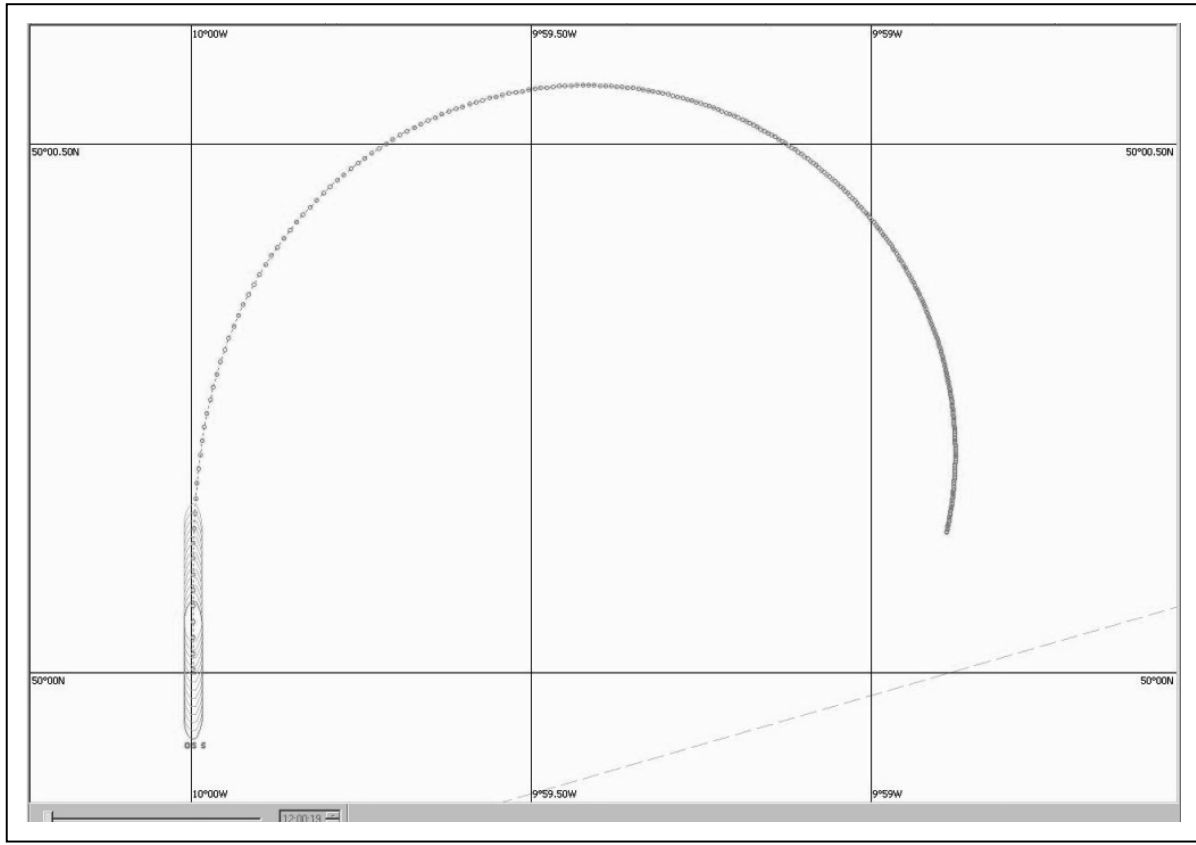

Figure 3 - Graphical display of the performed simulation

Source: Navigational simulator TRANSAS NTPro 4000

lected ship types represent specific types of vessels with greater water plane coefficient among which no significant differences in the shape of the hull and characteristics of propulsion and steering systems are present which allows a more valid analysis of the obtained results (Table 1 ).

After having selected certain ship types, the researched scenario was determined, in the process of which ship type, ship size, ship speed and rudder deflection angle were fluctuated.

For each ship type, four rudder deflection angles $\left(5^{\circ}, 10^{\circ}, 20^{\circ}\right.$ and $\left.35^{\circ}\right)$ and three different speeds (minimum, maximum, and $10 \mathrm{kn}$ - which is approximately the arithmetic mean of the minimum and the maximum speed of the selected vessels) were simulated.

A total of 60 scenarios were studied, and during the simulation, all relevant data concerning the cur- rent movement of the ship and a graphical display of the performed simulation (Figure 3) were recorded every 30 seconds. Numerical results of one of the performed simulations are shown in Table 2 and the selected scenarios are shown in Table 3.

\section{ANALYSIS AND DISCUSSION REGARDING THE RESULTS OBTAINED BY RESEARCH ON THE NAVIGATIONAL SIMULATOR}

The results obtained by the simulation on the nautical simulator were analyzed with respect to the risk of grounding during navigation in a limited area. The limited navigation area is a part of the fairway where navigational dangers, such as reefs, rocks, wrecks, shallow water areas, etc., are located close to the vessel. Fairways of such characteristics are located in ap- 
Đ. Mohović et al.: Simulation of Ship Movement After Steering System Failure to Determine the Worst Case Scenario of Grounding

Table 2 - Numerical display of records of the performed simulation

\begin{tabular}{|c|c|c|c|c|c|c|c|c|c|c|c|}
\hline \multicolumn{2}{|c|}{ Exercise: } & \multicolumn{10}{|c|}{ Ship movement simulation during an extraordinary event occurrence.nti } \\
\hline \multicolumn{2}{|c|}{ Own ship: } & \multicolumn{10}{|c|}{ OS 7 - Oil tanker (Dis.77,100 t) } \\
\hline \multicolumn{2}{|c|}{ Time interval: } & \multicolumn{10}{|c|}{ 00:00:00 - 00:16:14 } \\
\hline \multicolumn{2}{|r|}{ Step: } & \multicolumn{10}{|c|}{ 00:00:30 } \\
\hline TIME & LAT & LON & COG & SOG & HDG & LOG & SET & DRIFT & RUD & ROT & RPM L \\
\hline s & $\circ$ & $\circ$ & $\circ$ & $\mathrm{kn}$ & $\circ$ & $\mathrm{kn}$ & $\circ$ & $\mathrm{kn}$ & $\circ$ & $\% / \min$ & - \\
\hline 0 & 49.99999 & 9.99999 & 000 & 15.008 & 000 & 15.008 & 090 & 0.0 & 0 & 0.00 & 109 \\
\hline 30 & 50.00207 & 9.99999 & 000 & 15.053 & 002 & 15.048 & 271 & 0.4 & 5 & 7.00 & 109 \\
\hline 60 & 50.00417 & 9.99991 & 003 & 15.222 & 007 & 15.183 & 276 & 1.1 & 5 & 13.00 & 109 \\
\hline 90 & 50.00627 & 9.99961 & 008 & 15.020 & 015 & 14.913 & 284 & 1.8 & 5 & 18.00 & 51 \\
\hline 120 & 50.00825 & 9.99897 & 016 & 14.160 & 025 & 13.976 & 294 & 2.3 & 5 & 21.00 & 43 \\
\hline 150 & 50.01003 & 9.99794 & 025 & 13.210 & 036 & 12.977 & 305 & 2.5 & 5 & 21.00 & 39 \\
\hline 180 & 50.01156 & 9.99657 & 035 & 12.252 & 046 & 11.998 & 316 & 2.5 & 5 & 21.00 & 34 \\
\hline 210 & 50.01282 & 9.99494 & 045 & 11.357 & 057 & 11.098 & 327 & 2.4 & 5 & 20.00 & 2 \\
\hline 240 & 50.01380 & 9.99314 & 054 & 10.464 & 067 & 10.208 & 337 & 2.3 & 5 & 19.00 & 0 \\
\hline 270 & 50.01452 & 9.99128 & 064 & 9.678 & 076 & 9.433 & 346 & 2.2 & 5 & 18.00 & 0 \\
\hline 300 & 50.01500 & 9.98942 & 072 & 8.976 & 085 & 8.742 & 355 & 2.0 & 5 & 17.00 & 0 \\
\hline 330 & 50.01528 & 9.98760 & 080 & 8.358 & 094 & 8.136 & 003 & 1.9 & 5 & 16.00 & 0 \\
\hline 360 & 50.01539 & 9.98586 & 088 & 7.818 & 102 & 7.609 & 011 & 1.8 & 5 & 15.00 & 0 \\
\hline 390 & 50.01536 & 9.98423 & 096 & 7.331 & 109 & 7.131 & 019 & 1.7 & 5 & 14.00 & 0 \\
\hline 420 & 50.01520 & 9.98272 & 103 & 6.906 & 116 & 6.718 & 025 & 1.6 & 5 & 13.00 & 0 \\
\hline 450 & 50.01495 & 9.98132 & 109 & 6.522 & 122 & 6.344 & 032 & 1.5 & 5 & 12.00 & 0 \\
\hline 480 & 50.01462 & 9.98005 & 115 & 6.178 & 129 & 6.008 & 038 & 1.4 & 5 & 12.00 & 0 \\
\hline 510 & 50.01422 & 9.97891 & 121 & 5.867 & 135 & 5.706 & 044 & 1.4 & 5 & 11.00 & 0 \\
\hline 540 & 50.01378 & 9.97788 & 127 & 5.586 & 140 & 5.432 & 050 & 1.3 & 5 & 10.00 & 0 \\
\hline 570 & 50.01330 & 9.97698 & 132 & 5.330 & 146 & 5.182 & 055 & 1.2 & 5 & 10.00 & 0 \\
\hline 600 & 50.01279 & 9.97618 & 137 & 5.096 & 151 & 4.955 & 060 & 1.2 & 5 & 10.00 & 0 \\
\hline 630 & 50.01226 & 9.97548 & 142 & 4.882 & 156 & 4.746 & 065 & 1.1 & 5 & 9.00 & 0 \\
\hline 660 & 50.01172 & 9.97488 & 147 & 4.685 & 160 & 4.555 & 070 & 1.1 & 5 & 9.00 & 0 \\
\hline 690 & 50.01118 & 9.97437 & 151 & 4.503 & 165 & 4.378 & 074 & 1.1 & 5 & 8.00 & 0 \\
\hline 720 & 50.01063 & 9.97395 & 156 & 4.334 & 169 & 4.214 & 079 & 1.0 & 5 & 8.00 & 0 \\
\hline 750 & 50.01008 & 9.97360 & 160 & 4.178 & 173 & 4.062 & 083 & 1.0 & 5 & 8.00 & 0 \\
\hline 780 & 50.00954 & 9.97332 & 164 & 4.031 & 177 & 3.918 & 087 & 0.9 & 5 & 7.00 & 0 \\
\hline 810 & 50.00901 & 9.97311 & 168 & 3.896 & 181 & 3.788 & 091 & 0.9 & 5 & 7.00 & 0 \\
\hline 840 & 50.00849 & 9.97297 & 172 & 3.769 & 185 & 3.664 & 095 & 0.9 & 5 & 7.00 & 0 \\
\hline 870 & 50.00797 & 9.97288 & 175 & 3.650 & 189 & 3.548 & 098 & 0.9 & 5 & 7.00 & 0 \\
\hline 900 & 50.00748 & 9.97284 & 179 & 3.537 & 192 & 3.439 & 102 & 0.8 & 5 & 6.00 & 0 \\
\hline 930 & 50.00699 & 9.97284 & 182 & 3.431 & 196 & 3.335 & 105 & 0.8 & 5 & 6.00 & 0 \\
\hline 960 & 50.00653 & 9.97289 & 186 & 3.331 & 199 & 3.238 & 109 & 0.8 & 5 & 6.00 & 0 \\
\hline
\end{tabular}

Source: Navigational simulator TRANSAS NTPro 4000

proaches to ports and in ports, and in narrow channels or straits between island coasts and/or the inland.

Ship trajectories obtained on the basis of a certain scenario are analyzed for the case when the grounding isobath is 500 or $1,000 \mathrm{~m}$ from the planned trajectory. The grounding scenario analyzed is shown in Figure 4.
As determining the risk of grounding requires knowledge of grounding consequences as well as of the probability of occurrence, the ship speed was particularly analyzed. Ship speed and mass are the key parameters for determining the ship kinetic energy which is one of the factors necessary for assessing 


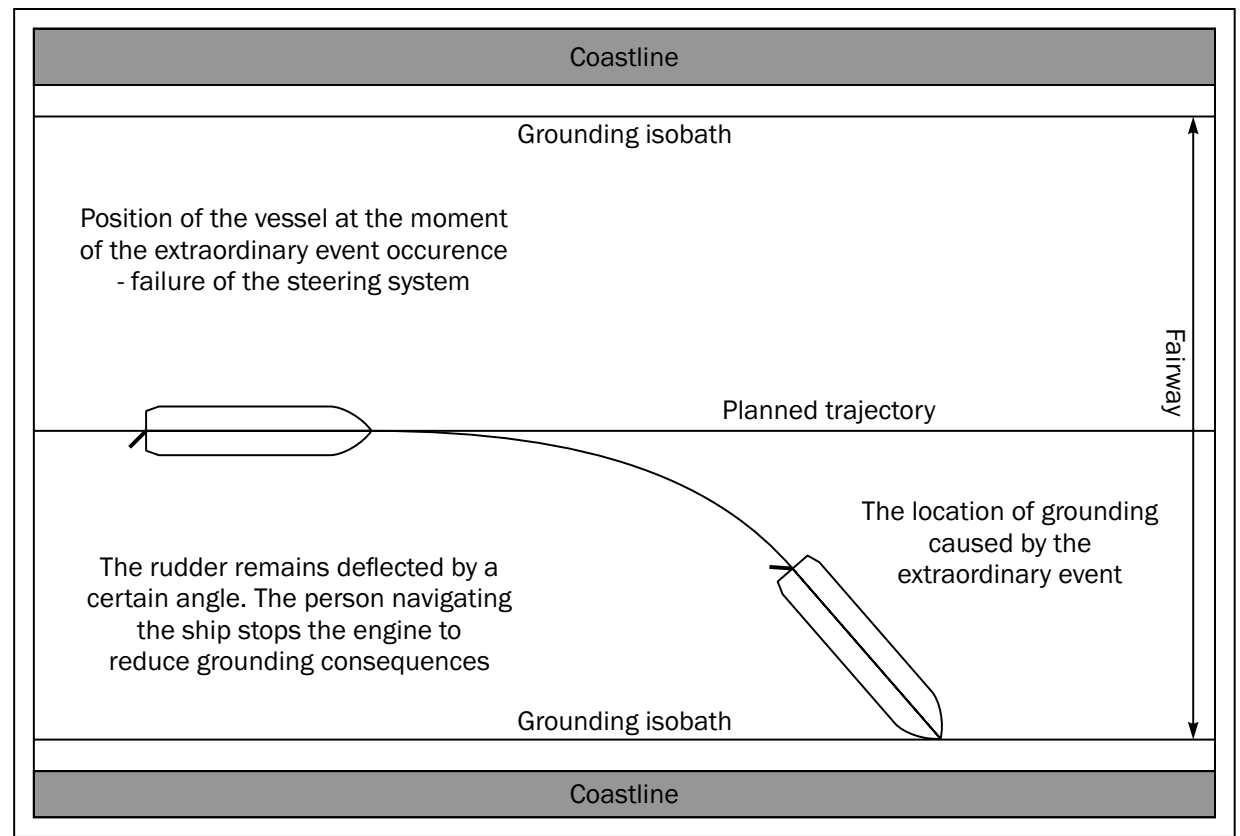

Figure 4 - Analyzed grounding scenario

the extent of damage caused by grounding. In turn, the extent of damage determines the consequence of grounding.

On the basis of the performed simulations of ship movements after the occurrence of the extraordinary event, the following analyses of the obtained results have been conducted:

- analysis of ship speed with various rudder deflections for the same initial speed when the grounding isobath is 500 or 1,000 metres from the vessel's planned trajectory,

- analysis of ship speed with different initial speeds, but with the same rudder deflection when the grounding isobath is 500 or 1,000 metres from the vessel's planned trajectory,
- analysis of ship speed for vessels of different sizes for the same scenario.

By comparing the ship movement simulations with the minimum rudder deflection angle from $5^{\circ}$ to a maximum of $35^{\circ}$, a conclusion was drawn that at the moment of grounding, when the grounding isobath is located 500 metres from the planned trajectory, the speeds are on the average $25 \%$ higher when rudder deflection angle is smaller, notwithstanding greater distance passed and longer time until grounding. Analysis of the same ship movement scenarios, but when grounding isobath is 1,000 metres from the planned trajectory, shows that speeds at the moment of grounding are on the average $60 \%$ higher when rudder deflection angle is $5^{\circ}$ than when it is $35^{\circ}$. On the

Table 3 - Overview of the results of the performed simulations

\begin{tabular}{|c|c|c|c|c|c|c|c|}
\hline \multirow{3}{*}{ Vessel type } & \multirow{3}{*}{ Displacement (t) } & \multirow{3}{*}{$\begin{array}{c}\text { Simulated speed } \\
(\mathrm{kn})\end{array}$} & \multirow{3}{*}{$\begin{array}{c}\text { Simulated rud- } \\
\text { der deflections } \\
\qquad\left(^{\circ}\right)\end{array}$} & \multicolumn{4}{|c|}{$\begin{array}{l}\text { Ship speed after the deviation } \\
\text { from the planned trajectory }\end{array}$} \\
\hline & & & & \multicolumn{2}{|c|}{$500 \mathrm{~m}$} & \multicolumn{2}{|c|}{$1,000 \mathrm{~m}$} \\
\hline & & & & $\mathrm{m} / \mathrm{s}$ & $\mathrm{kn}$ & $\mathrm{m} / \mathrm{s}$ & $\mathrm{kn}$ \\
\hline \multirow{12}{*}{ Chemical tanker } & \multirow{12}{*}{44,288} & \multirow{4}{*}{5.4} & 5 & 1.3 & 2.5 & 0.7 & 1.4 \\
\hline & & & 10 & 1.3 & 2.5 & 0.6 & 1.3 \\
\hline & & & 20 & 1.2 & 2.4 & - & - \\
\hline & & & 35 & 1.0 & 2.0 & - & - \\
\hline & & \multirow{4}{*}{10.0} & 5 & 2.6 & 5.0 & 1.5 & 2.9 \\
\hline & & & 10 & 2.5 & 4.9 & 1.4 & 2.7 \\
\hline & & & 20 & 2.4 & 4.7 & - & - \\
\hline & & & 35 & 2.1 & 4.1 & - & - \\
\hline & & \multirow{4}{*}{14.5} & 5 & 5.6 & 10.8 & 4.7 & 7.8 \\
\hline & & & 10 & 5.4 & 10.5 & - & - \\
\hline & & & 20 & 5.0 & 9.8 & - & - \\
\hline & & & 35 & 3.8 & 7.4 & - & - \\
\hline
\end{tabular}


Đ. Mohović et al.: Simulation of Ship Movement After Steering System Failure to Determine the Worst Case Scenario of Grounding

Table 3 - Overview of the results of the performed simulations (continued)

\begin{tabular}{|c|c|c|c|c|c|c|c|}
\hline \multirow{3}{*}{ Vessel type } & \multirow{3}{*}{ Displacement (t) } & \multirow{3}{*}{$\begin{array}{l}\text { Simulated speed } \\
(\mathrm{kn})\end{array}$} & \multirow{3}{*}{$\begin{array}{c}\text { Simulated rud- } \\
\text { der deflections } \\
\left({ }^{\circ}\right)\end{array}$} & \multicolumn{4}{|c|}{$\begin{array}{l}\text { Ship speed after the deviation } \\
\text { from the planned trajectory }\end{array}$} \\
\hline & & & & \multicolumn{2}{|c|}{$500 \mathrm{~m}$} & \multicolumn{2}{|c|}{$1,000 \mathrm{~m}$} \\
\hline & & & & $\mathrm{m} / \mathrm{s}$ & $\mathrm{kn}$ & $\mathrm{m} / \mathrm{s}$ & $\mathrm{kn}$ \\
\hline \multirow{12}{*}{ Oil tanker } & \multirow{12}{*}{77,100} & \multirow{4}{*}{5.5} & 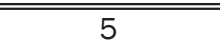 & 1.6 & 3.2 & 1.2 & 2.4 \\
\hline & & & 10 & 1.6 & 3.1 & 1.1 & 2.2 \\
\hline & & & 20 & 1.5 & 2.9 & 1.0 & 1.9 \\
\hline & & & 35 & 1.3 & 2.5 & 0.7 & 1.4 \\
\hline & & \multirow{4}{*}{10.0} & 5 & 3.1 & 5.9 & 2.3 & 4.5 \\
\hline & & & 10 & 3.0 & 5.8 & 2.2 & 4.2 \\
\hline & & & 20 & 2.8 & 5.4 & 1.8 & 3.5 \\
\hline & & & 35 & 2.4 & 4.7 & 1.4 & 2.7 \\
\hline & & \multirow{4}{*}{15.0} & 5 & 5.2 & 10.0 & 4.0 & 7.8 \\
\hline & & & 10 & 5.1 & 9.9 & 3.9 & 7.6 \\
\hline & & & 20 & 5.0 & 9.8 & 3.6 & 7.0 \\
\hline & & & 35 & 4.2 & 8.2 & 2.3 & 4.5 \\
\hline \multirow{12}{*}{ VLCC 4} & \multirow{12}{*}{137,092} & \multirow{4}{*}{5.8} & 5 & 2.0 & 3.8 & 1.5 & 3.0 \\
\hline & & & 10 & 1.9 & 3.8 & 1.5 & 2.8 \\
\hline & & & 20 & 1.8 & 3.5 & 1.3 & 2.5 \\
\hline & & & 35 & 1.6 & 3.1 & 1.0 & 1.9 \\
\hline & & \multirow{4}{*}{10.0} & 5 & 3.4 & 6.6 & 2.7 & 5.2 \\
\hline & & & 10 & 3.3 & 6.4 & 2.6 & 5.0 \\
\hline & & & 20 & 3.1 & 6.1 & 2.2 & 4.4 \\
\hline & & & 35 & 2.8 & 5.4 & 1.7 & 3.4 \\
\hline & & \multirow{4}{*}{14.7} & 5 & 5.6 & 11.0 & 4.7 & 9.2 \\
\hline & & & 10 & 5.5 & 10.8 & 4.5 & 8.6 \\
\hline & & & 20 & 5.4 & 10.5 & 4.1 & 7.9 \\
\hline & & & 35 & 4.5 & 8.8 & 2.7 & 5.2 \\
\hline \multirow{12}{*}{ Bulk currier } & \multirow{12}{*}{202,000} & \multirow{4}{*}{6.0} & 5 & 2.3 & 4.5 & 2.0 & 3.8 \\
\hline & & & 10 & 2.3 & 4.5 & 1.9 & 3.8 \\
\hline & & & 20 & 2.2 & 4.3 & 1.7 & 3.4 \\
\hline & & & 35 & 2.0 & 3.8 & 1.4 & 2.6 \\
\hline & & & 5 & 3.9 & 7.7 & 3.4 & 6.5 \\
\hline & & 100 & 10 & 3.9 & 7.7 & 3.3 & 6.4 \\
\hline & & 10.0 & 20 & 3.7 & 7.2 & 3.0 & 5.8 \\
\hline & & & 35 & 3.3 & 6.5 & 2.4 & 4.6 \\
\hline & & & 5 & 6.6 & 12.9 & 6.0 & 11.8 \\
\hline & & 146 & 10 & 6.5 & 12.6 & 5.8 & 11.3 \\
\hline & & 14.0 & 20 & 6.1 & 11.9 & 5.0 & 9.7 \\
\hline & & & 35 & 5.2 & 10.2 & - & - \\
\hline & & & 5 & 1.7 & 3.3 & 1.3 & 2.6 \\
\hline & & 55 & 10 & 1.7 & 3.3 & 1.3 & 2.5 \\
\hline & & 5.5 & 20 & 1.6 & 3.1 & 1.1 & 2.2 \\
\hline & & & 35 & 1.4 & 2.7 & 0.9 & 1.7 \\
\hline & & & 5 & 3.2 & 6.3 & 2.5 & 5.0 \\
\hline $\mathrm{VICC} 2$ & 321260 & 100 & 10 & 3.2 & 6.2 & 2.5 & 4.8 \\
\hline & & & 20 & 3.0 & 5.9 & 2.2 & 4.3 \\
\hline & & & 35 & 2.7 & 5.2 & 1.7 & 3.3 \\
\hline & & & 5 & 5.8 & 11.3 & 4.9 & 9.4 \\
\hline & & 157 & 10 & 5.8 & 11.2 & 4.6 & 9.0 \\
\hline & & 15.1 & 20 & 5.3 & 10.3 & 3.9 & 7.6 \\
\hline & & & 35 & 4.5 & 8.7 & 2.8 & 5.4 \\
\hline
\end{tabular}


basis of the shown results, it can be concluded that during navigation in narrow fairways, the rudder deflection angle has less effect on the grounding speed than in wider fairways.

The maximum speed simulated is on the average 2.6 times higher than the minimum simulated speed. The ship speed at the moment of grounding when the grounding isobath is 500 metres from the planned trajectory in the movement simulation with maximum initial speed is on the average 3.2 times higher than the ship speed at the moment of grounding in the movement simulation with the minimum initial speed for the same rudder deflection angle. The results of the same simulations when the grounding isobath is 1,000 me tres from the planned trajectory are very similar. The above mentioned results lead to the conclusion that a certain correlation is present between the difference between the minimum and the maximum initial speed, and the difference of the grounding speed with respect to the initial speeds. Furthermore, it is completely logical to conclude that lower initial speed results in lower grounding speed.

With larger vessels, the speed at the moment of grounding for the same scenarios was higher than with smaller vessels, except for the largest simulated ship "VLCC 2". Although the displacement of "Bulk carriers" is almost 5 times greater than the displacement of "Chemical Tankers", when the grounding isobath is 500 metres from the planned trajectory, at the moment of grounding, the speed is on the average $85 \%$ greater than the speed at the moment of grounding of a smaller vessel with the minimum simulated initial speeds. When the same scenario is studied for the highest simulated speeds, at the moment of grounding of a larger vessel, the speed is on the average 30\% higher than the speed at the moment of grounding of a smaller vessel. If the two already mentioned scenarios are analyzed in the fairway where the grounding isobath is 1,000 metres from the planned trajectory, it is concluded that the speed at the moment of grounding of the larger vessel will be on the average 170\% higher than the speed at the moment of grounding of a smaller vessel with the minimum simulated initial speeds, and on the average 50\% higher with the maximum simulated speeds. Based on the displayed results, it can be concluded that during navigation in narrower fairways the difference in ship displacement will have a lesser effect on the speed of the grounding than during navigation in wider fairways.

With regards to the aim of this paper, from the above mentioned analyses a conclusion was reached that the worst case scenario of grounding for all simulated vessels will occur when the rudder deflection angle is small. If the acceptable risk of grounding is to be determined, it is necessary to apply the principle of the worst case scenario which leads to the conclusion that during data set creation, the number of simula- tions can be reduced, i.e. it is sufficient to simulate only the smallest rudder deflection angle $\left(5^{\circ}\right)$ and to vary ship sizes and initial speeds. Rudder deflection angles smaller than $5^{\circ}$ are very small rudder deflections, and in view of the extraordinary events analyzed in this paper, they are considered to be the ship track head reach that will not result in greater drifting from the planned trajectory unless the vessel is affected by external forces.

\section{CONCLUSION}

Analyzing the ship movement trajectory after the occurrence of the extraordinary event mentioned in this paper, it can be concluded that during navigation in narrow fairways, the rudder deflection angle has less effect on the grounding speed than in wider fairways. Also, a certain correlation is present between the difference between the minimum and the maximum initial speed, and the difference of the grounding speed with respect to the initial speeds. Further, it can be concluded that during navigation in narrower fairways the difference in ship displacement will have a lesser effect on the speed of grounding than during navigation in wider fairways.

By comparing the ship movement simulations with different rudder deflection angles, it was concluded that the worst case scenario during grounding will occur when the rudder deflection angle is small. Based on this finding, it can also be concluded that during data set creation, the number of simulations can be reduced, i.e. it is sufficient to simulate only the smallest rudder deflection angle $\left(5^{\circ}\right)$.

The performed simulations can only be applied to bulk carriers and tankers. Further research should define scenarios for other types of ships, as well as for other types of extraordinary events. Also, the obtained results will be validated in future research by comparison with data obtained in experiments with real vessels using various predetermined trajectories.

On the basis of the simulation results, it is possible to develop a simulation model that would provide a ship movement curve in case of an assumed extraordinary event, and then grounding parameters would be obtained for the selected width of the fairway (to the grounding isobath). The grounding parameters are input data for determining the extent of vessel damage in case of grounding, which finally defines the consequence of grounding, one of the parameters necessary for the assessment of the risk of grounding.

\section{ACKNOWLEDGMENTS}

Authors thank Dean Bernečić, Ph.D. for help during the analysis of ship systems that directly or indirectly affect the capacity to control ship speed and direction. 
Dr. sc. ĐANI MOHOVIĆ

E-mail: dmohovic@pfri.hr

Dr. SC. ROBERT MOHOVIĆ

E-mail: mohovic@pfri.hr

Dr. Sc. IGOR RUDAN

E-mail: rudan@pfri.hr

Sveučilište u Rijeci, Pomorski fakultet

Studentska 2, 51000 Rijeka, Hrvatska

\section{SAŽETAK}

\section{SIMULACIJA KRETANJA BRODA NAKON KVARA KORMILARSKOG UREĐAJA RADI UTVRĐIVANJA NAJNEPOVOLJNIJEG DOGAĐAJA PRI NASUKANJU}

Nasukanje broda spada u osnovne pomorske plovidbene nezgode, a nastaje zbog pogreške osobe koja upravlja brodom, tehničkog kvara na vitalnim dijelovima opreme broda, a može nastati i zbog više sile. Kako bi se smanjio rizik nasukanja u takvim slučajevima, u radu je istraženo kretanje broda tijekom plovidbe kada na brodu dolazi do izvanrednog događaja kao što je kvar sustava kormilarskog uređaja koji izravno utječe na smjer broda, a posredno i na brzinu broda. Jedan od načina određivanja kretanja broda u takvim okolnostima, što je prikazano $u$ ovom radu, je simuliranje kretanja broda na navigacijskom simulatoru prema unaprijed definiranim scenarijima. Na navigacijskom simulatoru ukupno je istraženo 60 scenarija, pri čemu je varirana vrsta broda, veličina broda, brzina broda i kut otklona kormila. Tijekom provođenja simulacije svakih $30 \mathrm{~s}$ bilježeni su svi bitni podaci o trenutnom kretanju broda te grafički prikaz izvedene simulacije. Na osnovu rezultata simulacija moguće je odrediti najnepovoljniji događaj koji se može upotrijebit za određivanje posljedice nasukanja, što je jedan od elemenata potrebnih za procjenu rizika nasukanja.

\section{KLUUČNE RIJEČI}

rizik nasukanja, kvar sustava kormilarskog uređaja, simulacija kretanja broda, odabir najnepovoljnijeg događaja

\section{REFERENCES}

[1] IMO, Formal Safety Assessment, MSC 83/INF.2, 2007

[2] Fowler, T.G., Sørgård, E.: Modeling ship transportation risk, Risk Analysis, 20, (2000) 2, 225-244

[3] Amrozowicz, M., Brown, A., Golay, M.: A Probabilistic analysis of tanker groundings, $7^{\text {th }}$ International Offshore and Polar Engineering Conference, Honolulu, Hawaii, 1997
[4] Simonsen, B.C., Hansen, P.F.: Theoretical and Statistical Analysis of Ship Grounding Accidents, Journal of Offshore Mechanics and Arctic Engineering, 2000, 122: 200-207

[5] Bielić, T., Mandžuka, S., Tomas, V.: Model of ship management in emergency, Promet-Traffic \& Transportation, Vol. 23, 2011, No. 6, 471-483

[6] Lin, R. Q., Smith, T., Hughes, M.: Prediction of Ship Unsteady Maneuvering in Calm Water by a Fully Nonlinear Ship Motion Model, Modelling and Simulation in Engineering, Volume 2012, Article ID 468029, 2012

[7] Lin, R.Q. and Kuang, W.: A fully nonlinear, dynamically consistent numerical model for ship maneuvering in a seaway, Modeling and Simulation in Engineer, vol. 2011, Article ID 356741, 2011

[8] Lin, R.Q., Hughes, M., and Smith, T.: Prediction of ship steering capabilities with a fully nonlinear ship motion model. Part 1: maneuvering in calm water, Journal of Marine Science and Technology, vol. 15, no. 2, 2010, 131-142

[9] Kang, D., Nagarajan, V., Hasegawa, K., Sano, M.: Mathematical model of single-propeller twin-rudder ship, Journal of marine science and technology, Volume 13, No. 3, 2008, 201-222

[10] Sutulo, S., Moreira, L., Guedes Soares, C.: Mathematical models for ship path prediction in manoeuvring simulation systems, Ocean Engineering, Volume 29, Issue 1, 1-19, 2002

[11] Cahill, R.A.: Strandings and their causes, $6^{\text {th }}$ ed., The Nautical Institute, London, 2002

[12] Kristiansen, S.: Maritime transportation safety management and risk analysis, Elsevier Butterworth-Heinemann, Oxford, 2005

[13] Vinnem, J.E.: Offshore risk assessment, Kluwer Academic Publishers, Dordrecht, 1999

[14] Diamantidis, D.: Risk acceptance criteria, Joint Committee of Structural Safety, JCSS, Document \#3, 2008

[15] Friis-Hansen, P., Simonsen,B. C.: GRACAT: software for grounding and collision risk analysis, Marine Structures 15 (2002), 383-401

[16] Kite-Powell, H.L. et al.: Investigation of potential risk factors for groundings of commercial vessels in U.S. ports, International Journal of Offshore and Polar Engineering, 9 (1999), 1, 16-21

[17] Jebsen, J.J., Papakonstantinou, V.C.: Evaluation of physical risk of ship grounding, PhD Thesis, Massachusetts Institute of Technology, 1997

[18] Capability of ship manoeuvring simulation models for approach channels and fairways in harbours, PIANC, 1992 